\title{
Bir İngiliz Oryantalistin Portresi: Edward William Lane (1801-1876)
}

\section{Portrait of a British Orientalist: Edward William Lane (1801-1876)}

\author{
Selda Güner Özden* (1)
}

"Doç. Dr., Hacettepe Üniversitesi, Edebiyat Fakültesi, Tarih Bölümü, Ankara, Türkiye

\section{ORCID: S.G.Ö. 0000-0002-0669-8900}

Sorumlu yazar/Corresponding author: Selda Güner Özden,

Hacettepe Üniversitesi, Edebiyat Fakültesi, Tarih Bölümü, Ankara, Türkiye

E-posta/E-mail: sguner@hacettepe.edu.tr

Başvuru/Submitted: 27.05.2020 Revizyon Talebi/Revision Requested: 28.10.2020

Son Revizyon/Last Revision Received: 04.11.2020

Kabul/Accepted: 27.12 .2020

\section{Atıf/Citation:}

Guner Ozden, Selda. "Bir Ingiliz Oryantalistin Portresi: Edward William Lane (1801-1876)." Tarih Dergisi-Turkish JournalofHistory,73(2021):149-172. https://doi.org/10.26650/iutd.743219

\section{öz}

Napolyon Bonapart'ın 1798'deki işgali Mısır'ı oryantalizmin temalarından biri haline getirdi ve Avrupa'da "Piramitler Diyarı"na yönelik merak ve seyahatleri tetikledi. Bonapart'dan 27 yıl sonra genç bir İngiliz, Edward Willian Lane (18011876) uzun bir gemi yolculuğundan sonra Temmuz 1825'de Mısır'a gelerek, Kahire'de sıradan Mısırlıların arasında yaşamayı tercih etti. Mısır'a farklı zamanlarda gerçekleştirdiği üç seyahatinin neticesinde eserlerini kaleme almıştır. Eski ve modern Mısır'ın büyük kısmını dolaşan Lane gözlemlerini, halkın inanç, dil, örf ve adetlerini Description of Egypt, An Account of the Manners and Customs of the Modern Egyptian, Binbir Gece Masalları ve ArapçaIngilizce Sözlük gibi geniş çapta okunan eserlerde kaydetti. Mısır'a ilk gelişinde Antik Mısır'a dair çalışmalar yaparken, zamanla dikkatini çağdaşı Mısırlıların dil ve kültürleri çekmişti. Bir oryantalist olarak Lane'nin çalışmalarının hususiyeti, "bilimsel" bir yaklaşımla Mısır ve Mısırlıları anlatmaya çalışmasıydı.

Bu makale bir şarkiyatçı olarak Edward William Lane'nin Mısır tetkikleri içindeki yerini muhtelif boyutlarıyla incelemeye çalışacaktır.

Anahtar sözcükler: Edward William Lane, Mısır, Kahire, Oryantalizm

\section{ABSTRACT}

Napoleon Bonaparte's invasion in 1798 made Egypt one of the themes of orientalism and sparked curiosity and travels towards the "Land of the Pyramids" in Europe. 27 years after Bonaparte, a young Englishman Edward William Lane (1801-1876) arrived in Alexandria in July 1825 after a long cruise. He preferred to live among ordinary Egyptians in Cairo. Edward William Lane wrote his works as a result of his three trips to Egypt at different times. Traveling through much of ancient and modern Egypt Lane immersed himself in a contemporary Egyptian lifestyle and described it vividly. He recorded his observations, beliefs, languages, customs and traditions of the people in his works such as Description of Egypt, An Account of the Manners and Customs of the Modern Egyptian, Thousand and One Nights, Selections from Kur'ân and also Arabic-English Lexicon. During his first visit to Egypt, while working on Ancient Egypt, in time he was interested in Arabic and culture of the contemporary Egyptians, their daily lives and customs. At this point, the specialty of Lane's works as a orientalist was to explain Egypt and Egyptians with a "scientific" eye. This article will examine Edward William Lane's place in Egyptian studies in various dimensions as an Orientalist.

Keywords: Edward William Lane, Egypt, Cairo, Orientalism 


\section{Extended Abstract}

Studies of orientalism take their arguments from the conflict areas of imperialism and antiimperialism. Consequently, information about the East produced by western orientalists has been questioned, accused of being biased or rejected completely. Of course, Edward Said had an important influence on this after the seventies. Said argued in a critical way that the East was the most important external "reality" of modern Europe. Today we call this "the other" or "otherisation". Although we are discussing orientalism within the boundaries of political history or generalization of Eastern through the eyes of the West/Western conceptions of the Orient, we take advantage of its experience at the point we have reached today. The rise in the generation of orientalist knowledge, especially in the 19th century, is remarkable. One case in point is that, Europeans of the early $19^{\text {th }}$ century were keenly interested in the mysterious and enormous remains of the ancient Egyptian civilizations. Among them was a twenty-fouryear-old Englishman, Edward William Lane (1801-1876) who wrote as a result of three trips to Egypt undertaken at different times. Lane's first trip to Egypt was between 1825-1828, his second trip between 1833-1835, and his third journey between 1842-1849. The Society for the Diffusion of Useful Knowledge supported his travels to Egypt, because Lane did not have any job or salary. Sometimes assistance was provided by socially eminent figures, such as Algernon Percy, the $4^{\text {th }}$ Duke of Northumberland, and John Russell, $1^{\text {st }}$ Earl Russell.

Various biographies of Lane's life have already been written. Leila Ahmed wrote first modern biographical assessment, Edward W. Lane: A Study of His Life and Works and of British Ideas of the Middle East in the Nineteenth Century (1978). It was followed by Jason Thompson's Edward William Lane The Life of the Pioneering Egyptologist and Orient (2010). These two biographical works are largely based on his letters to friends. Ahmed's book can also be considered as a cultural history because of focusing on the nature of Lane's published works. On the other hand, Jason Thompson's study succeeded in completing the missing pieces of Lane's life by used archival resources such as private manuscripts and letters at the Griffith Institute in Oxford, as well as papers of Lane's close friends Sir Gardner Wilkinson and Joseph Bonomi at the Bodleian Library. Thompson was rightly aware that Lane's life could not be understood without considering his activities and, for this reason, consulted the testimony of Egyptologists such as Joseph Bonomi, Robert Hay, and John Gardner Wilkinson who were in contact with him.

Lane recorded his observations and researches on the space, structures and habitats, traditions and cultures of ancient and modern Egypt in his Description of Egypt (not published until 2000), An Account of the Manners and Customs of the Modern Egyptians (1836), One Thousand and One Nights (1840), Selections from Kur'ân (1843) and an Arabic-English Lexicon (first volume, 1863). After Lane finally left Cairo in 1849, he started working on 
Arabic-English Lexicon, devoting himself to the dictionary until he died in 1876.

During his first visit to Egypt, while working on Ancient Egypt, in time he became interested in Arabic and the culture of contemporary Egyptians, their daily lives and customs. At this point, the focus of Lane's work was to explain Egypt and Egyptians with a scientific eye. He wrote his books for the early Victorian English reading public. Based on personal experience, especially in An Account of the Manners of the Modern Egyptians, he presented the British people a peerless tableux of a Egyptian society. Actually Lane began to work as an engraver, not an orientalist, Arabist or writer. When Lane first went to Egypt in 1825 with a new drawing device, camera lucida. His drawings via the camera lucida and their explanations were included in his work Description of Egypt which was not published until 2000.

Lane tried to live like an Egyptian during his travels. He immersed himself in a contemporary Egyptian life and described it vividly. His lifestyle made it possible for him to observe Egyptian society closely, spending time in coffee houses and praying in mosques. Lane traveled to Egypt at a time when Istanbul and Cairo began separating administratively and militarily. However, this separation was not included in his studies. Turks were still regarded as elite in the eyes of Egyptian society. Because of this, Lane dressed in Ottoman style, never dressing in European clothing during his life in Cairo. According to him, Ottoman meant Turk and vice versa. However, Lane was interested in the native culture, not the ruling or bureaucratic elites. He resided at Cairo, at different times. As his pursuits required that he should not draw attention in public as a European, he separated himself as much as possible from the Europeans and lived in a part of the town, near Babu'l-Hadid, somewhat remote from the Frank quarters. Lane built a Muslim identity for himself using the name Mansur Efendizâde. He was able to adapt easily to the life of the Egyptians: speaking Arabic and conforming with the manners of his Muslim neighbors. As he reported, Lane was treated with respect and affability by all the Egyptians with whom he had any dealings.

There are a limited number of studies about the Victorian orientalist Edward William Lane (1801-1876) by Turkish scholars since Lane dealt with Arabic and especially Egypt. If he had been a traveler whose road passed by Istanbul and Anatolia, he would have attracted more Turkish readers and researchers. Such being the case, the aim of this essay is to introduce a British Arabist- Orientalist researcher and his works, which came to Ottoman Egypt with a great curiosity in the 19th century, to more Turkish readers. I trace Lane's character and his studies of folklore in the contexts of orientalist discourses. This paper examines how Egypt was perceived by Lane at a time when Egyptian society was beginning to be modernized. What makes Lane important for the Turkish reader is that he witnessed Egyptian society at a time when power was passing from the Ottoman administration to Mehmed Ali Pasha's. 


\section{Giriş}

“1872 yılında, Trieste'de, sütunları rutubetten nemli ve sıhhi tesisatı bozulmuş bir sarayda, yüzü Afrika'da aldığı yaranın izini taşıyan bir beyefendi -İngiltere Konsolosu Yüzbaşı Richard Francis Burton-, Rumilerin Binbir Gece Kitabı diye adlandırdıkları Elf Leyle ve Leyle'nin ünlü çevirisine girişiyordu. Bu çevirinin gizli amaçlarından biri, İngiltere'de kapsamlı bir sözlük hazırlayan, kendisi gibi Mağribilere özgü kara sakallı ve teni de güneşten kararmış bir beyefendiyi yok etmekti ancak Burton amacına ulaşamadan hayata veda etti. Bu kişi Galland'ın çevirisini gölgede bırakan, Binbir Gece'nin olanca titizlikle gerçekleştirilmiş diğer çevirisinin sahibi Şarkiyatçı Edward William Lane'di."'

19. yüzyılda Mısır Avrupalı gezginler için cazip bir yer haline geldi. Başlangıçta, tehlike ve gizem havası Mısır'1 öncelikle Avrupalı asiller, maceracılar, oryantalistler ve sanatçılar için ilgi odağı yapmıştı. Birçok Avrupalı seyyah Osmanlı yönetici eliti veya Mısırlı ahali arasında yıllarca yaşamış, hatta bazıları yerel kıyafet ve yaşam tarzlarını benimseyerek Mısır'da dolaşabilmişti. Osmanlı Arap coğrafyasının bu mümtaz eyaletine İngiliz Oryantalist Edward William Lane de ilgi göstermiştir. Mısır'a ilk defa gidişi 1825-1828 yılları arasındadır, 18331835 yılları arasında ikinci ve 1842-1849 arasında da üçüncü seyahatini gerçekleştirmişti. Bu çalışma Lane'nin Doğusu olarak Mısır ve Mısırlıları nasıl tasvir ettiğini kişisel serüveni ve eserlerinden hareketle anlatmaya çalışacaktır.

Edward William Lane'e dair Türkçe bir tetkik, ilkin ansiklopedik-didaktik bir mecrada ilerlemek zorundadır. Nitekim Türkiye'de Lane hakkında literatür oldukça zayıftır. Bu makale dolayısıyla öncelikle tanıtıcı- malumat verici bir boyut içermekte ve fakat sadece bununla yetinmemekte, onun cehdinin farklı boyutlarını dikkate almaktadır. Bu farklı boyutlar nelerdir? Başka bir ifadeyle Lane'e, Batı'daki Doğu ilgisinin, Garb âleminde Şark'a/ötekiye yönelik çok değişik veçhelere bürünmüş ilgi, imge ve disiplinlerin tarihçesi içerisinde kendine ait bir yer açan faktörler neler olmuştur? sorularına cevap aranacaktır.

17 Eylül 1801'de Hereford'da doğan Lane, Theophilus Lane (1764-1814)'in üçüncü çocuğuydu. Theophilus Lane, Hereford'un hukuk doktoralı papazıydı; Edward William Lane'in annesi, Ressam Gainsborough'nun yeğeni Sophia Gardiner'dır. Lane, Bath ve Hereford Gramer Okullarında (Grammar Schools) ilk eğitimini alarak, daha sonra Cambridge'e gider, ancak kısa süre sonra üniversiteden ayrılır. Daha sonra Londra'ya kardeşi Richard James Lane (1800-1872)'nin yanına taşınır ve gravür üzerine çalışmaya başlar. ${ }^{2}$

1 Richard F. Burton, Binbir Gece Masalları, Haz. Jorge Luis Borges, Çev. Gülgün Bayata, Kırmızı Kedi Yay., İstanbul 2015, s. 5.

2 Stanley Lane-Poole, Life of Edward William Lane, Williams and Norgate, London, 1877, s. 10-14, Leila Ahmed, Edward William Lane, A Study of his Life and Works and of British Ideas of the Middle East in the Nineteenth Century, Longman, London 1978, s. 1. 
Richard J. Lane, başarılı bir Victoria çağı gravürcüsü ve litografçısıydı. ${ }^{3}$ Lane'nin Londra'da bir oryantalist olarak hayata atılmadığı ilk zamanlarına dair bu bilgilerden anlaşılmaktadır. Fakat Londra'daki günlerine dair bilgilerimiz sınırlıdır.

Lane’nin oryantalizmi Arapçaya merakından kaynaklanmaktadır. Zira Arap dili ve kültürüne ilgisi araştırmalarına yön vermiştir. O Mısır'a her geldiğinde bir kitap ya da eser projesiyle İngiltere'ye dönmüştür. Eserleri arasında, Description of Egypt, An Account of the Manners and Customs of the Modern Egyptians (1836), The Thousand and One Nights (1839-41) çevirisi, Selections from the Kuran (1843) ve the Arabic-English Lexicon (1863-93) en meşhurlarıdır. Hatta The Arabic-English Lexicon (Arapça-İngilizce Sözlük) hem Arap ve hem de Batılı öğrenci ve araştırmacılar için türünün önde gelen bir örneği olmaya devam etmektedir. ${ }^{4}$

Londra'da yaşayan Lane'in Mısır'a artan ilgisi ve Arapça öğrenmeye başlaması onu seyahate sevk etmişti. Mısır'a olan merakı ilk defa Napolyon'un Mısır seferi sonucunda ortaya çıkan yayınlar, özellikle de Description de l'Egypte'le başlamıştı. ${ }^{5}$ İkincisi, Misırbiliminin (Egyptoloji) ilk önemli isimlerinden Giovanni Battista Belzoni (1778-1823) 1821'de Londra, Piccadilly'de Mısır antikaları sergisini açtığında, İngilizlerin ve özellikle de Lane'in dikkatini bu konuya çekmişti. ${ }^{7}$ Bundan bir kaç sene önce 1818 'de, İngiltere'nin

3 İlk sergisini 1824 'de Royal Academy'de açan ve 1837 'de Kraliçe Victoria tarafindan Kraliyet Litografi olarak atanan Richard James Lane'ın portre ve figürlerden oluşan yaklaşık 850 litografı The National Portrait Gallery'de (Londra) sergilenmektedir. Bkz. https://www.npg.org.uk/collections/search/person/mp06039/ richard-james-lane?search=sas\&sText=Richard+James+Lane\&OConly=true (Erişim Tarihi: 11.04.2020)

4 Arthur Goldschmidt Jr., Historical Dictionary of Egypt, Scarecrow Press, Plymouth 2013, s. 241.

5 Description de l'Égypte, birinci cildi 1809 ve son cildi 1829 'da basılan bu eser, eski ve modern Misır'ın bilinen tüm yönlerini ve doğal tarihini kapsamlı bir şekilde kataloglamayı amaçlamıştır. Eserin farklı edisyonları da bulunmakta ve cilt sayıları değiş̧mektedir. https://gallica.bnf.fr/services/engine/search/ sru?operation $=$ searchRetrieve \&version $=1.2$ \&page $=1$ \&query $=($ gallica $\% 20$ all $\% 20 \% 22$ description $\% 20 \mathrm{de} \% 20$ 1\%27egypte\%22) (Erişim Tarihi: 09.04.2020), ayrica bkz. Dennis Porter, Haunted Journeys: Desire and Transgression in European Travel Writing, Princeton University Press, Princeton 2014, s. 164-165.

6 Belzoni, Mısır'da arkeolojik sit alanlarındaki kazılarıyla tanınmıştır. 1803'de İngiltere'ye yerleşmiş, 1812'de İngiltere'den ayrılıncaya kadar sirklerde çalışmıştır. 1815'de Mısır'a gitmiştir. Hidrolik motor modelleri üzerinde çalışan Belzoni, Mehmed Ali Paşa'dan umduğu ilgiyi göremeyince yeni bir kariyere adım atmıştır: Mısır mezar ve tapınaklarını gün yüzüne çıkarmak. Onu bu yeni kariyerine yönlendirenler, oryantalist Johann Ludwig Burckhardt ve İngiltere'nin Misır konsolosu Henry Salt (1780-1827)'dı. Nitekim Konsolos tarafindan Mısır'ın Teb'deki Ramesseum harabelerine gönderilmiş ve burada başarılı işler yapan Belzoni, Firavun II. Ramses (the Young Memnon)'in bir büstünü ortaya çıkartmıştı. En önemlisi 16 Ekim 1817'de I. Seti'nin mezarının açılmasında o da bulunmuştur. Gize'deki Kefren piramidinde ilk kazıyı yine Belzoni yapmıştı. 1819 senesinde Londra'ya döndükten sonra Mısır'daki faaliyetlerini İngilizlerin ilgisine sundu. Belzoni, 1823 'de Benin'de dizanteriden ölmüștür. Giovanni Battista Belzoni, Narrative of the Operations and Recent Discoveries Within the Pyramids, Temples, Tombs and Excavations, in Egypt and Nubia, c. 2, John Murray, London 1820; J. J. Halls, The Life and Correspondance of Henry Salt Esq. Frs. His Britannic Majesty's Late Consul General in Egypt, c. 2, Richard Bentley, London 1834, s. 17, 19, 31-37. Stanley Mayes, The Great Belzoni, The Circus Strongman Who Discovered Egypt's Ancient Treasure, Bloomsbury, London 2003.

7 Arthur John Arberry, British Orientalists, William Collins, London 1943, s. 19-20.

Jason Thompson, "Edward William Lane's 'Description of Egypt"', International Journal of Middle East Studies, 28, 4, 1996, s. 565, Roper, Geoffrey, "Texts from Nineteenth Century Egypt: The Role of E. W. Lane”, Travellers in Egypt, ed. Paul Starkey, Janet Starkey, I. B. Tauris, London 1998, s. 244. 
Mısır konsolosu Henry Salt (elçiliği 1815-1827), maceracı ve kaşif Belzoni’yi Teb'deki kazıda çalışması için görevlendirmiş ve Ramses'in meşhur büstünü çıkardıktan sonra Henry Salt'ın takdim yazısıyla Quarterly Review' da yayınlamıştı. ${ }^{8}$ Salt, ünlü gezgin Burckhardt ${ }^{9}$ ve John Gardner Wilkinson ve Belzoni gibi isimlerle antik Misır arkeolojik alanlarına merakını göstererek, Mısır'ın karanlıkta kalan antik mazisinin gün 1şığına çıkarılmasına destek vermişti. Böyle bir dönemde Mısır'a ilk seyahatini 1825'de gerçekleştiren Lane, bir süre Henry Salt'1n oldukça himaye ve desteğini gördü. ${ }^{10}$

18 Temmuz 1825 Pazartesi günü Lane, İskenderiye’ye doğru "Findlay" isimli gemiyle yola çıktı. Bu Mısır'a ilk seyahatiydi ve üç yıl sürecekti." "Kıyıya yaklaşırken gelinin duvağını kaldırıp, onu ilk defa görecek Doğulu bir damat gibi hissettim, beğenebilir, hayal kırıklığına uğrayıp nefret de edebilirdim" 12 diye o anki hislerini tarif etmiştir. "Mısır'ı bir gezgin olarak sadece piramitlerini, tapınaklarını ve mağaralarını incelemek için ziyaret etmiyordum, merakımı tatmin ettikten sonra diğer yerleri ve zevklerini de tatmak istiyordum. Fakat kendimi tamamen yabancılar arasına atmak üzereydim; dillerini, geleneklerini ve kıyafetlerini benimsemek ve neredeyse sadece yerlilerle ilişki kurarak, edebiyatlarını takip etmek için"13 Mısır'a gelmiştir.

O dönem Konsolos Henry Salt'ın misafirperverliği Lane'in hayatını kolaylaştıracaktır. Ona Babü's-Sidr yakınlarındaki kır evinde bir oda vermişti. Lane, Salt'ın evinde kaldığı sürede bir muhit edinmişti. Konsolosu ziyaret edenler arasında Mısır'ın tartışılmaz en meşhur kartografı M. Linant'la arkadaşlığı buna örnek verilebilir. ${ }^{14}$ Diğer taraftan Henry Salt, Lane'e dair izlenimlerini anlatmıştı:

“...Çok çalışkan ve Arapçası büyük bir ilerleme kaydetti... Aynı zamanda cana yakındı ve elindeki kısıtlı parayla yaşıyordu. Onun için yapabileceğim her şey bir zevk. Bana, litografide büyük bir hayranlık duyduğum kardeşi tarafindan yapılmış birkaç baskı verdi." ${ }^{15}$

Lane Kahire'de artık tamamen bir “Doğulu” gibiydi: Batılı kıyafetlerini çıkarıp Mısır'da bulunduğu tüm süre boyunca sadece yerel kıyafetler giydi. Sadece maddi kültüre dahil olmak

8 Shadia Mahmoud, "Nationalization and Personalization of the Egyptian Antiquities: Henry Salt a British General Consul in Egypt 1816 to 1827", International Journal of Culture and History, 3, 2, 2016, s. 36.

9 Bkz. John Lewis Burckhardt, The Manners and Customs of the Modern Egyptians, London 1775, John Carne, Recollections of Travels in the East, London, 1830, s. 248.

10 Ahmed, Edward William Lane, s. 24-25, Deborah Manley, Peta Rée, Henry Salt: Artist, Traveller, Diplomat, Egyptologist, Libri Publications Ltd., London 2001, s. 94, 160, 137, 151, 213.

11 Lane-Poole, Life of Edward William Lane, s. 15.

12 Edward William Lane, Description of Egypt, ed. Jason Thompson, The American University in Cairo Press, Cairo 2000 s. 4.

13 Lane, Description of Egypt, s. 5.

14 Lane-Poole, Life of Edward William Lane, s. 20-21.

15 J. J. Halls, The Life and Correspondance of Henry Salt ESQ. FRS. His Britannic Majesty's Late Consul General in Egypt, II, Richard Bentley, London1834, s. 273-274. 
için değil aynı zamanda, Mısır toplumunun detaylı bir bilgisine sahip olabilme adına bu kıyafetlere ihtiyacı vardı. Lakin, Lane'in seçtiği elbise elbette sıradan bir Mısırlınınkine benzemiyordu. Mısır'daki yönetici Türk elitinin bir üyesi gibi giyinerek bir nevi koruyucu bir zırh edindi. Zira o senelerde Mısır'da hâlâ Osmanlı idaresi ve memurlarının nüfuzu hissediliyordu. Başlangıçta sadece bir gözlemci gibi davranan Lane, bir dükkânın önünde oturup kahve ve nargile içerek etrafı izler. Daha sonra ise Müslümanların hayatına karışmaya başlayarak, onlarla birlikte camide namaz kılar ve hatta buradaki ders halkalarına katılır. Bunları yaparken Kahire'nin yerlisi gibi yaşamaya özen gösterir. Onları adeta içlerinden biriymiş gibi müşahede etme niyetindedir. Bu bilinçli tercih onu "Frenk" mahallesi yerine otantik Kahire'nin bir semti Babü'l-Hadîd'de yaşamaya sevk etti. ${ }^{16}$ Bu tercih Kahire'deki Frenk muhitlerin ona sağlayacağı konfor ve imtiyazlardan gönüllü bir feragati işaret eder. Fakat ona asıl gayesini yani Arapça diyalektlere hakimiyeti ve böylece Kahire halkının örf ve adetlerinin içeriden bir gözlemcisi olmayı kazandırdı. O bu açıdan sadece oryantalist değil, yerliler arasında yıllar geçiren modern bir antropologdur. Bir yıl içinde Arapçayı akıcı konuşmaya başlar. Artık onu Mansur ismiyle tanıyan geniş bir Mısırlı arkadaş çevresi de edinir. Mansur ismi onun Mısırlı kimliği olur. ${ }^{17}$ Lane her hâlükârda Mısır'a gerçekleştirdiği bu ilk seyahatte halinden memnundu: "Misırlılarca el üstünde tutuldum"18 diyecektir.

Lane'nin Kahire'deki araştırmalarını kolaylaştıran iki kaynak vardı: Birincisi doğrudan tecrübeydi. Alışveriş yapmak, arkadaşlarını ziyaret etmek ve misafir kabul etmek gibi günlük aktiviteler, dikkatli bir gözlemciye çok şey öğretebilecek temel etkileşim şekliydi. İslam hakkında pratik detayları öğrenerek Kahire'nin camilerinde cemaatle ibadet etti. Bu, Description of Egypt'de de belirttiği gibi o sıralar Batılı bir kişinin kolayca yapamayacağı bir şeydi. ${ }^{19}$

Mısır'a ilk gelişinde Lane, Kahire'nin anıtlarını ve mahallelerini inceledi, kent hakkında neredeyse uzmanlaştı. Önceleri ilgi alanı Kahire çevresindeki arkeolojik alanlardı ve ziyaretlerinin büyük bölümünü antik yapıların olduğu yerler oluşturuyordu. Bunun yanı sıra Lane, Nil boyunca Nubya'daki İkinci Şelale'ye ${ }^{20}$ kadar iki uzun seyahat gerçekleştirmişti. Birincisi, 1826’da, Mart ortasından Ekim sonuna kadar yedi buçuk ay sürdü. Diğer taraftan, $\mathrm{Bu}$ seyahatleri sırasında çeşitli zorluklarla da karşılaştığı anlaşılmaktadır. Mesela Nisan

16 Lane, Description of Egypt, s. 5-6, Ahmed, Edward William Lane, s. 26.

17 Bazı çalışmalarda Mansurefendizâde olarak geçmektedir. Philip Charles Sadgrove, İsmail Durmuş, "Lane, Edward William", DİA, 27, 2003, s. 99-100, Ali Bilgenoğlu, Selahattin Ertürk Çiftçi, "Bir Batılı Seyyahın Hatıralarında Oryantalizm'in İzlerini Sürmek: Edward William Lane’in Gözünden 19. Yüzyıl Misır Toplumu ve Kültürü”, Tarih Okulu Dergisi, 11, XXXVI, 2018, s. 45. Ayrıca Mısır'da tanıştı̆̆ John Gardner Wilkinson ile İngiltere'ye döndükten sonra da görüştükleri ve mektuplarında birbirlerine Mısır'da kullandıkları isimlerle (İsmail ve Mansur) hitap etmeye devam ettikleri anlaşılmaktadır. Bkz. Jason Thompson, Sir Gardner Wilkinson and His Circle, University of Texas Press, Texas 2013, s. 139,

18 Lane, Description of Egypt, s. 90.

19 Lane, a.g.e., s. 79-84.

20 Lane-Poole, Life of Edward William Lane, s. 29. 
sonuna doğru Lane, İngiliz Misırbilimci James Burton (1786-1862)21 ile birlikte Dendara’ya gitmiş ancak hamsin rüzgarlarının olumsuz şartları sebebiyle, tekneyi terk edemedikleri için hiçbir çizim yapamamışlardı. ${ }^{22}$

İkincisini de arkadaşı Robert Hay (1799-1863)'le ${ }^{23}$ 1827'nin Haziran-Aralık ayları arasında gerçekleştirdi ve Nubya'ya kadar meşhur arkeolojik alanları inceledi. ${ }^{24}$ Lakin Lane'nin seyahatleri sınırlı bir alanı kapsar, Mısır'ın Doğu veya Batı çöllerine hiç gitmedi, böylece meslektaşları James Burton (1786-1862) ve Wilkinson (1797-1875)'u²5 büyüleyen antik harikaları göremedi. Diğer taraftan Lane, Mısır dışında başka bir Ortadoğu coğrafyasına da hiç seyahat etmedi. Elbette Lane'in Yukarı Mısır ve Nubya seyahatlerinin asıl gayesi kişisel olarak eski Mısır'a olan merakını tatmin etmekti. Fakat Lane Mısır'ı resimlerle belgeledi, yanında hiç gravürcüsü olmamasına rağmen, aldığı çizim eğitimi, gözlemlediği şeyleri çizmesini ve daha sonra eskizlerini kitap resimlerine dönüştürmesini sağladı. Resim kabiliyeti ailesiyle de ilişkilendirilebilir, nitekim daha önce de belirtildiği gibi, büyük amcası ünlü sanatçı Thomas Gainsborough'du; ayrıca kardeşi Richard J. Lane, 19. yüzyıl İngiltere'sinin önde gelen litograflarından biriydi. ${ }^{26}$

Lane'in ilk Kahire izlenimi hayal kırıklığına uğramadığını gösteriyor. Şehir ve buradaki her şey tamamen "Doğu'ya uygun"du: Düz çatılı/teraslı evler, gök yüzüne uzanan sayısız minare ve kalenin taçlandırdığı kent silueti onu etkilemişti. ${ }^{27}$ Modern Mısır'da hayat, en az antik dönem kadar seyyahların ilgisini çekecek güzellikteydi.

21 Gerçek adı James Haliburton olan James Burton 1820-1837 yılları arasında Mısır'da yaşamış ve Krallar Vadisi’nin keşfi ve haritalandırılmasında önemli bir rol oynamıştı. Thompson, Sir Gardner Wilkinson and His Circle, 2013, s. 10, 90, 131. Richard A. Davies, Inventing Sam Slick: A Biography of Thomas Chandler Haliburton, University of Toronto Press, Toronto 2005, s. 71.

22 Lane-Poole, a.g.e, s. 31.

23 Robert Hay, 1826-1838 yılları arasında Mısır'da bir arkeolojik keşif gezisinin önde gelen üyelerinden biriydi. Mezkûr yıllar arasında arkadaşları arasında Edward W. Lane de vardı. Hay, Nil boyunca keşif gezileri yaparak antik tapınak ve mezar yerlerini kaydetmişti. Hatta gezilerde bulduğu mezar veya tapınakların eskizlerini çizerek ve kısa açıklamalarını yapmakla yetinmemiş, mimari planları, yazıtlar ve duvar resimlerinin detaylı kopyalarını da hazırlamıştır. Çizimleri için Kamera Lucida kullanmıştır. Heykeltıraş Joseph Bonomi (17961878) ve mimarlık eğitimi alan Francis Arundale (1807-1853)'den seyahatleri sırasında çizimleri için yardım almıştır. Bu gezilere Lane'nin de eşlik ettiği bilinmektedir. Robert Hay'in yaşam öyküsünde Lane'ninkine benzeyen bir durum da İskenderiye'den satın aldığı Giritli Kalitza Psaraki ile evlenmiş olmasıdır. Nitekim Lane de Nefise isimli köle pazarından aldığı bir kadınla evlenmişti. 1840'da yayınlanan Illustration of Cairo hariç, Hay'ın çalışmalarından hiçbiri basılmadı. Zira 1840'da basılan Litograflar' '1, fahiş fiyatı sebebiyle çok satmamıştı. Aynı durumla karşılaşan Lane'nin de Description of Egypt'1, kitapta yer alan litografların yüksek maliyeti sebebiyle yayınlanamamıştı. Robert Hay, Illustration of Cairo, Tilt and Bogue, London 1840, Sarah Searight, The British in the Middle East, Elton Press, London 1979. s. 238-241, Jane Waldron-Grutz, "The Lost Portfolios of Robert Hay", Saudi Aramco World, 54, 2, March/April 2003. s. 2-11.

24 Halls, The Life and Correspondence of Henry, s. 273.

25 Wilkinson'a Lane'e ilham vermesi bakımından önem atfetmemizin sebebi Kahire'de ve daha sonra İngiltere'de sürdürdükleri arkadaşlığın yanı sıra, Wilkinson'un $1837^{\prime}$ de 3 cilt halinde basılan Manners and Customs of the Ancient Egyptians, isimli eseridir.

26 Lane-Poole, Life of Edward William Lane, s. 29.

27 Lane-Poole, a.g.e., s. 31. 
Lane'nin, Haziran 1828'de İngiltere'ye döndüğünde kitab1, Description of Egypt'1 yazmak için elinde bol miktarda yazılı ve görsel malzeme vard1. Description of Egypt temelde bir gezi günlüğü olarak organize edilmiş bir metin olmasına rağmen, seyahatlerinin güzergahı ile hiçbir ilişkisi olmayan uzun açıklama parçaları içermektedir. Eserde Mısır'ın antik dönemine yer vermeye çalışırken bir taraftan da çağdaşı Mısırlıların geleneklerinden bahsediyordu. Ayrıca Lane, bu çalışmasında Kahire'ye önemli bir yer ayırır. Şehrin sokaklarının, büyük caddelerinin, çarşılarının ve büyük camilerinin ayrıntılı bir izahını sunmaktadır. ${ }^{28}$ Diğer taraftan Description of Egypt'da Lane, Thomas Young (1773-1829) ve Jean François Champollion (1790-1832)'un keşiflerinden ortaya çıkan bilgilerin üzerine eski anıtları inceleyip, tasvir ederek Nil'in ikinci şelalesine kadar yer vermektedir. Bu seyahatleri sırasında, Arapça bilgisi sayesinde Mısırlılarla kolayca temas kurabilmiş, hayat biçimlerini ve geleneklerini öğrenme şansına sahip olmuştu. Lane'nin seyahatlerini gerçekleştirdiği dönemde, Mısır'da Avrupa etkisi henüz yeni yeni hissediliyordu. Bu yüzden Lane, Misır'ın kendine has karakterini bir bütünlük içinde inceleyebildi. Aslında Lane Mısır'ı kendisine bir meslek edinmişti. Mısır'da kaldığı bu sürenin sonunda ülkenin, halkın ve anıtların detaylı bir tasvirini yapmıştır. Description of Egypt'in Mısır'a dair farklı veçheleri sunmasının sebebi de buydu. Nitekim eserde Kahire Kalesi hakkında mimari bilgilere ulaşabileceğimiz gibi, Mehmet Ali Paşa'nın Mısır'da iktidarı nasıl ele geçirdiğini anlatan bir siyasi tarih bilgisine de ulaşabiliriz. Antik Mısırlıların kökenleri ve fiziksel özelliklerinden, dönemin Nubyalılarının tarımsal faaliyetlerine kadar Mısır'a dair çok katmanlı bir repertuar ortaya çıkarır. ${ }^{29}$ Ayrıca bu kitapta, arkadaşı Dr. Wallaston'ın icadı kamera Lucida'yla 160 sepya resim Lane'in Misır tasvirinin görsel belgelerini oluşturuyordu. Description of Egypt'da yer alan detaylı açıklamalar ve çizimler, eserin orijinal taraflarını oluştursa da resimlerin çoğaltılmasının yüksek maliyeti sebebiyle 2000 senesine kadar yayınlanmad $1 .{ }^{30}$ İngiltere'ye döndüğünde Lane bu çok yönlü çalışmasının taslağını Lord Brougham (1778-1868)'a sunmuştu. Bunun akabinde Lord Brougham'ın kurucusu olduğu Yararlı Bilginin Yayılması Cemiyeti (the Society for the Diffusion of Useful Knowledge), ${ }^{31}$ Lane'e Description of Egypt'in içinde

28 Edward William Lane, Description of Egypt, Ed. Jason Thompson, American University in Cairo, Cairo 2000, s. 67-93.

29 Lane, a.g.e., s. 444-462.

30 Lane-Poole, Life of Edward William Lane, s. 11-12, Lane, Description of Egypt, s. XIV.

31 The Society for the Diffusion of Useful Knowledge, 1826'da bir Whig milletvekili ve Benthamit faydac1s1 Lord Henry Brougham tarafından kuruldu. Cemiyet, yetenekli işçi sınıfı erkeklerine ve ailelerine hizmet etmek için eğitimi yaymak isteyen "devlet adamları, avukatlar ve hayırseverlerden” oluşuyordu. Aslında bu cemiyet, işçi sınıfını hedefleyen ve sınıflar arası gerginlikleri azaltmak umuduyla eğitimi yaygınlaştırmayı amaçlayan üst orta sınıf kurumlardan biriydi. Lord Brougham özgür bir eğitim sistemi kurma konusunda son derece idealistti. Sadece the Society for the Diffusion of Useful Knowledge'ın kurulmasiyla yetinmeyecek aynı zamanda University of London, the London Mechanics Institution'ın da teşekkülünde rol oynadı. Ayrıca, 1820'de “İngiltere ve Galler' deki yoksulların eğitimi” konulu bir yasa tasarısını parlamentodan geçirmeyi başardı. Bkz. John McGilchrist, The Life and Career of Henry Lord Brougham, Cassell, Petter, And Galpin, London 1868, s. 121, 126. Mitchell, Mısır'ın Sömürgeleştirilmesi, s. 188, Rasoul Aliakbari, "The Arabian Nights in the English Popular Press and the Heterogenization of Nationhood: A Print Cultural Approach to Benedict Anderson's Imagined Communities," Canadian Review of Comparative Literature / Revue Canadienne de Littérature Comparée, 43, 3, 2016, s. 443. 
yer alan modern Mısırlıların hayatlarıyla ilgili kısımları yayınlamayı teklif etmiş, lakin o bu teklifi kabul etmemiştir. ${ }^{32}$

1833 baharında Lane, İngiliz tarihçi Henry Hart Milman (1791-1868)'1n tavsiyesiyle modern Mısırlıların adet ve gelenekleri hakkında bir kitap yazmaya karar verir ve Description of Egypt'dan çıkardığı bölümleri temel alarak çalışmaya başlar. Bu yeni projesi için Yararlı Bilgileri Yayma Cemiyeti Lane'e kitap için bir sözleşme teklif etti. Lane, ihtiyacı olan malzemeleri toplamak için Mısır'a gitmesi şartıyla teklifi kabul etmiş ve bu sayede Aralık 1833'te An Account of the Manners and Customs of The Modern Egyptians isimli eseri hakkında çalışmak için yola çıkmıştı.

\section{Mansur Efendi ve "Modern Misırlıların Örf ve Adetlerinin Bir Açıklaması"}

1833 Aralık ayı sonunda Kahire'ye ulaştığında Lane, araştırma tekniğinin önemli bir bileşeni olan Mısır yaşam tarzına yeniden uyum sağlayarak, tekrar Mansur ismini kullanmaya başladı. Elbette bu defa ne aradığını ve nereye bakması gerektiğini biliyordu. Bu sebeple ertesi yıl Eylül ayında neredeyse tüm verilerini toplamıştır. Aralık 1834'de An Account of the Manners and Customs of The Modern Egyptians'ın taslağını hazırlamıştı. ${ }^{33}$ Lakin İngiltere'ye dönmesine mani olan bir durum -veba- ortaya çıktı. 1835'teki veba salgını sırasında Kahire'den ayrılarak Teb'e gitmiş, buradaki antik eserlerle ilgilenerek vakit geçirmişti. Bu salgında 80 bin insan öldü, Lane'e göre bu, nüfusun üçte biriydi. ${ }^{34}$ " 4 Ocak 1835- veba İskenderiye'nin ötesine yayıldı... Hemen Kahire’ye yayılması beklendiği için vebadan kurtulmak için Teb'e gitmeye hazırlanıyorum. Bay Fresnel bana eşlik edecek..."35 Lane, Teb'de Şeyh Abdu'l-Kurna tepesinde bir mezar evinde beş ay daha geçirir. Bu sebeple ancak 1835 sonbaharında İngiltere'ye dönebildi ve Aralık 1836' da An Account of the Manners and Customs of the Modern Egyptians yayınland1. Edward Said, The Modern Egyptians üzerinden Lane'e eleştiriler yöneltmişse de "Tarih ve antropoloji incelemelerinde bir temel yapıt olmasının kitabın (...) biçeminden, zekice, dâhice ayrıntılarından kaynaklandığının..."36 altını da çizmiştir.

32 Edward William Lane, An Account of the Manners and Customs of the Modern Egyptians, 1973, s. VI.

33 Sadgrove, Durmuş, "Lane, Edward William", s. 100.

34 Edward William Lane, An Account of the Manners and Customs of the Modern Egyptians: The Definitive 1860, American University in Cairo Press, New York 2003, s. 3, Ayrica bkz. Thompson, "Osman Effendi: A Scottish Convert to Islam in Early Nineteenth-Century Egypt”, s. 119. Başka bir kaynakta sadece 1835 Martı'nda İskenderiye'de ölenlerin sayıs 4250 olarak zikredilmektedir. Bkz. John Bowring, Report on Egypt and Candia Adressed to the Right Hon. Lord Viscount Palmerston, Her Majesty's Principal Secretary of State for Foreign Affairs, W. Clowes and Sons, London 1840, s. 10.

35 Lane-Poole, Life of Edward William Lane, s. 75

36 Edward W. Said, Şarkiyatçılık Batı'nın Şark Anlayışları, Çev. Berna Ülner, Metis Yay., İstanbul 2001 , s. 24. Ayrica bkz. Abdul Latif Tibawi, English-Speaking Orientalists A Critique of Their Approach to Islam and Arab Nationalism, Islamic Centre, Geneva 1965, s. 10, Bilgenoğlu, Çiftçi, "Bir Batılı Seyyahın Hatıralarında”, s. 51. 
Lane, The Modern Egyptians'da Mehmed Ali Paşa'nın idaresinde ve hâlâ bir Osmanlı eyaleti olan Mısır'ın “örf ve adetlerini” anlatmaktadır. Ona göre Mehmed Ali Paşa, her ne kadar sultana sadakatini bildirmiş olsa da, Mısır'da mutlak bir egemendi. Hatta Lane, Mehmed Ali Paşa'dan, sert bir hükümdar olarak bahseder ve onun karakteristik özelliklerini tarif ederken, selefi Memluk beylerinden ayıran hususu, halka keyfi zulüm etmemesi olarak açıklar. ${ }^{37}$ Ona göre Mehmet Ali Paşa reformları sadece bürokrasi ve orduyu dönüştürmekle kalmamış Kahire de bundan etkilenmiştir. Lane, Kahire'de meydana gelen değişimin, iktidar seçkinlerinden daha öteye ulaşmadığını iddia etmekle birlikte, şehrin bir başkent statüsü kazandığı ve aynı zamanda bir hanedanın merkezi olduğunu belirtir. ${ }^{38}$ Avrupalı mimarların elinin değdiği yapılar ve caddeler karşısında, "dar sokaklar, türbeler ve hamamlar vardı; kıvrımlı demir ızgaralı çeşmeler ve ahşap kafeslerle taranan pencereler; Kıpti kiliseleri ve camilerin minareleri, incelikle işlenmiş mumlar gibi gökyüzüne yükseliyordu." The Modern Egyptians'da geçen bu ifadeler şehrin geleneksel veçhesinin modern olana hâlâ yenilmediğini gösteriyor. Lane, Kahire'yi gezdiğinde, eski şehrin çevresindeki mahallelerdeki hayatı gözlemlemişti. Mesela Yahudi mahallesinden geçerken gördüklerini şöyle tarif eder: "Birbiriyle kesişen perişan, dar ve pis bir mahalle, hatta iki kişinin yan yana yürümekte zorlanacağ kadar dar sokaklar..."39 $\mathrm{Bu}$ satırlar bize 19. yüzyılın ilerleyen safhalarında göreceğimiz Kahire'nin düalist imajını betimlemektedir. Bu imaj daha sonra Timothy Mitchell'in Avrupalıların Kahire'yi tanımlamak için kullandıkları terimle "sergi olarak şehir"dir..

Kahire'deki bu ikinci ikametinde de Edward William Lane, Arapların dil ve kültürlerini yakından inceler. Elbette eski Kahire'de Babü'l Hadîd yakınlarında ikamet ediyor ve hâlâ bir Osmanlı eliti gibi giyiniyordu. Zira Kahire ve İskenderiye'nin dışında Batılı giysiler içinde dolaşan yabancılar alay konusu olmaya ve bazen de taşlanmaya maruz kalabiliyordu. ${ }^{41}$ Lane'in Kahirelilerin hayatına dair bilgi toplama ve bunları not etmesinde asıl adı Willim Taylor ${ }^{42}$ olan Osman Efendi (1784-1835)'nin rolü büyüktür. Aslında Osman Efendi sadece Lane’e değil neredeyse 1835 yılında ölünceye kadar yolu Kahire'ye düşmüş tüm İngiliz seyyahlar ile Mısır toplumu arasında arabulucu olarak önemli bir işlev yerine getirmişti. ${ }^{43}$ Lane'nin Osman

37 Lane, the Modern Egyptians, s. 24, 108, 110.

38 Heba Farouk Ahmed, Pre-Colonial Modernity: The State and the Making of Nineteenth-Century Cairo's Urban Form, Yayınlanmamış Doktora Tezi, University of California, Berkeley, 2001, s. 57.

39 Lane, the Modern Egyptians, s. 553. Ayrica Bkz. Deborah A. Starr, "Sensing the City: Representations of Cairo's Harat al-Yahud”, Prooftexts, 26, 1-2, 2006, s. 140, Alsayyad, Cairo: Histories of a City, s. 189-190.

40 Timothy Mitchell, Mısır'ın Sömürgeleştirilmesi, Çev. Zeynep Altok, İletişim Yay., İstanbul 2001, s. 27-36.

41 Robert Irwin, Oryantalistler ve Düşmanları, Çev. Bahar Tırnakcı, Yapı Kredi Yayınları, İstanbul 2008, s. 168.

42 Bazı kaynaklarda gerçek ismi William Thomson olarak zikredilmektedir. Bkz. Jason Thompson, "Osman Effendi: A Scottish Convert to Islam in Early Nineteenth-Century Egypt”, Journal of World History, 5, 1 1994, s. 100-101.

43 Thompson, “Osman Effendi: A Scottish Convert to Islam”, s. 100. Osman Efendi’nin yardımına ve arkadaşlığına mazhar olmuş İngiliz seyyahlar ve ondan bahsettikleri eserlerin listesi için bkz. R. Madden, Travels in Turkey, Egypt, and Palestine in 1824,1825,1826, 1827, c.1, London, 1829, s. 345 46; John Madox, Excursions in the Holy Land, Egypt, Nubia, Syria, c.1, London, 1834, s. 107; Joseph Moyle Sherer, Scenes and Impressions in 
Efendi vasıtasıyla sıradan Mısırlıların hayatına dâhil olduğunu görmekteyiz. The Modern Egyptian, doğum ve ölümden, sünnet ve evlilik, cenaze törenleri, bayramlar, batıl inançlar, müzik ve kıyafetler ya da dinî ritüellere kadar sıradan hayatın tüm aşama ve özelliklerinin bir toplu anlatımıdır. Lane'in Mısır'da gözlem yaperken Arapça bilen bir Avrupalı olarak hedefi yazdıklarının yerliler için değil, Avrupa ve Avrupa kültürünü yaymayı amaçlayan kurumlar için yararlı bilgiler ihtiva etmesiydi. Elbette bu şekilde Lane, sadece izleyen değil, sergileyendir aynı zamanda. ${ }^{44}$ Onun oryantalizme Mısır özelinde yaptığı katkı tam olarak buydu.

The Modern Egyptian'da Lane Mısırlıların özellikle hicivden hoşlandıklarını belirtmektedir. Ona göre alaycı şakalar ve jestleri dikkate değerdi. "Dilleri onlara şımarık ve imalı konuşmalar için harika olanaklar sağlıyordu. Bazen şarkılarda yöneticilerini hicveder ve yasalarla alay ederlerdi." ${ }^{45}$ Lane'nin anlattığı her konu veya kavrama, ayrıntılı bilgi veya örnekler verdiğini görmekteyiz. Mesela hiciv konusunu işlerken, devlete borçlu olduğu vergiyi ödeyecek gücü olmayan bir fellahın ana kahraman olduğu 1833'deki bir sokak oyununu bir siyasî hiciv örneği olarak detaylı bir biçimde anlatmaktadır. Hikâyeye göre, vergisini ödeyemediği için, dövülmüş ve hapsedilmiş hikâyenin kahramanı, karısını rüşvet vermeye ve daha sonra bir hükümet yetkilisini kocasını hapishaneden çıkarması şartıyla baştan çıkarmaya yöneltmiştir. ${ }^{46}$ Ona göre, hicvin gücünü anlamamızı sağlayan asıl husus konuşma dilinde (ammice) söylenen şiirlerin tipik bir biçimde kahvehanelerde, berberlerde ve diğer kamusal buluşma yerlerinde küçük dinleyici grupları için yüksek sesle okunmasıdır. ${ }^{47}$

Lane, The Modern Egyptian'da sadece Kahirelilerin eğlence ve karakter özelliklerini anlatmaz, siyasi tarihe de değinir. Örneğin Selahaddin Kalesi, Mehmed Ali Paşa kendi ismini taşıyan camisini orada inşa etmeye başladığında neredeyse yedi yüzyıl yaşındaydı. Bu kaleden, Eyyubi, Memlük ve Osmanlı İmparatorluğu yöneticileri tüm Mısır'ı idare etmişti. Kale, hükümetlerin değişmesi veya değişen ittifaklarla ilişkili bir yerdi. Yüzyıllar boyunca kentin sakinleri ve ziyaretçilerini idare eden bir mekand1. ${ }^{48}$ Lane'nin eseri Kahire özelinde Mısır'ın mekân ve tarih ilişkisini inşa etmeyi başarmıştır. Lane, ayrıca, şehri sembolize eden mekân veya binaları tarif ederek Kahire imgesini güçlendirir. ${ }^{49}$

Egypt and in Italy, London, 1824, s. 182-83; William Holt Yates, The Modern History and Condition of Egypt, c.1, London, 1843, s. 285-93; John Carne, Recollections of Travels in the East, London, 1830, s. 325-31; Anne Katherine Elwood, Narrative of a Journey Overland from England, c.1, London, 1830, s.137-64, Thomas Legh, Narrative of a Journey in Egypt and the Country beyond the Cataracts, London 1816, s. 129, Deborah Manley, The Nile A Traveller's Anthology, Cassell, London 1996.

44 Said, a.g.e., s. 171.

45 Lane, the Modern Egyptians, s. 308. Ayrıca bkz. Ziad Fahmy, Ordinary Egyptians, Creating the Modern Nation Through Popular Culture, Stanford University Press, Stanford 2011, s. 42.

46 Lane, a.g.e., s. 126-128.

47 Lane, a.g.e., s. 384-385, Fahmy, Ordinary Egyptians, s. 42.

48 Lane, The Modern Egyptians, s. 110, ayrica bkz. Stanley Lane-Poole, The story of Cairo, J. M. Dent Co., London 1906, s. 164-192. Ayrica bkz. Janet Abu-Lughod Cairo: 1001 Years of the City Victorious, Princeton University Press, Princeton 1971, s. 173.

49 Nezar Alsayyad, Cairo: Histories of a City, Belknap Press of Harvard University Press, Cambridge 2011, s. 171. 
Eserleri her ne kadar daha sonraki birçok oryantalist veya bilimsel eserin temelini oluştursa da, The Modern Egyptians, daha sonra "nesnellik eksikliği”" sebebiyle eleştirildi. Zira Lane, Mısır halkını değişmesi zor bir cemiyet olarak tarif eder. ${ }^{50}$ Diğer taraftan The Modern Egyptians'da, İslam'ın sadece bir inanç olarak değerlendirilemeyeceğini, zira toplum ve kültürün ana formunu oluşturduğunu düşünüyordu. "Müslümanlar öncelikle Peygamberlerinin rehberliğinde hareket ederler" demektedir. ${ }^{51}$ Lane, bir yabancının bakış açısıyla İslam'a ve topluma baksa da, eleştiriden uzak bir üslupla onu olduğu gibi tarife çalışır. İnancın ameli ve itikadi taraflarına dair verdiği bilgiler, Kuran'a hâkim olduğunu göstermektedir. Ayrıca bir Hıristiyan olarak Lane, Kuran'ın Hz. İsa'ya bakış açısını da okuyucuya açıklayarak, Müslümanlığın İsa'nın öğretisiyle kurduğu bağa dikkat çekmektedir. ${ }^{52}$

Kitabında Mısırlıların kahve, tütün, esrar, afyon kullanımına yer verirken, "aylaklığın neredeyse her kesimden Mısırlıyı esir aldığı"nı söyler. ${ }^{53}$ Mısırlıların bu özelliklerini eserde fazla ön plana çıkarması sebebiyle nesnel bir yaklaşımı olmadığına dair eleştirilir. Zira diğer oryantalistler gibi Doğu toplumlarını "tembel, miskin ve keyif verici maddelere düşkün" olarak tarif eden genellemeci bir yaklaşım sergilemekle itham edilir. Buna rağmen The Modern Egyptians'da tek taraflı bir anlatımın olmadığını da söylemek mümkündür. Nitekim eserin konusu Mısır'ın kozmopolit nüfus özellikleri kadar renklidir. Müslüman Araplar kadar bu eserde Mısırlı Kıptilerin toplumsal hayatına dair detaylı bilgiler yer almaktadır. ${ }^{54}$ Lane, The Modern Egyptian'1 İngiliz okuyucusuna etnografik bir anlatı olarak sunmuştu. Hatta ona göre amacı, İngilizlere "dünyanın en ilginç milletlerinden birini, en büyük Arap şehrinin sakinlerinin detaylı bir resmini çizerek" anlatmak veya tanıtmaktı. ${ }^{55}$ Lane, işi hikâye anlatmak olan insanlardan dinlediklerini ve kendi topladığı anekdotlardan halk hikayelerini bir araya getirmeye çalışmıştı. Bu sebeple onu tarif ederken sadece oryantalist demek yerine, kimi zaman halkbilimci veya folklorcu tabirleri de kullanılabilir. ${ }^{56}$ Lane'in 1825 -1828 ve 1833 1835 yılları arasında Mısır'da geçirdiği günlere istinaden yazdığı eseri, yerlilerin arasına karışması ve onlar gibi yaşamasının bir neticesi olarak ortaya çıktı. Bu haliyle, Lane'in Mısır'daki ikameti bir "bilimsel" gözlem niyeti taşıyordu. ${ }^{57} \mathrm{Bu}$ sebeple onun the Modern Egyptians'1 oryantalizme bilimsel malzeme sağlamak gibi bir göreve sahipti. ${ }^{58}$ Lane ve eseri

\footnotetext{
50 Lane, a.g.e., s. 303.

51 Lane, a.g.e., s. 66.

52 Lane, a.g.e., s. 64-65.

53 Alsayyad, Cairo: Histories of a City, s. 190.

54 Lane, a.g.e., s. 530-547.

55 Roper, "Texts from Nineteenth Century Egypt", s. 245-246.

56 Richard Dorson, Folktales of Egypt, ed. ve trans. Hasan-al-Shamy, Chicago, 1981.

57 Robert Irwin, "The Arabian Nights and the Origins of the Western Novel”, Scheherazade's Children: Global Encounters with the Arabian Nights, ed. Marina Warner and Philip Kennedy, New York UP, 2013, s. 143-153, Robert Irwin, "Political Thought in the Thousand and One Nights", The Arabian Nights in Transnational Perspective, ed. Ulrich Marzolph, Wayne State UP, 2007, s. 149, Aliakbari, "The Arabian Nights in the English Popular Press", s. 452.

58 Said, a.g.e., s. 169, 171, 175. Ayrıca bkz. Bilgenoğlu, Çiftçi, "Bir Batılı Seyyahın Hatıralarında”, s. 45.
} 
hakkında farklı fikirler, tartışmaların olduğunu söylemek yanlış olmaz. Örneğin Irwin, Said'in tezine karşı çıkarak, Lane'in eserinin kendini daha genel bir okur kitlesini eğitmeye adamış bir dernek (the Committee of the Society for the Diffusion of Useful Knowledge) tarafindan desteklenerek basıldığını öne sürer. ${ }^{59}$ Stanley Lane-Poole de, the Modern Egyptians'1 "bir halkın hayatının şimdiye kadar yazılmış en mükemmel resmi”" olarak nitelendirmiştir. ${ }^{60}$ Lane'in the Modern Egyptians' $\imath$ Doğulu bir topluma dair bilgi kaynağı olarak değerlendirilebileceği gibi, "akademik oryantalizm"in gelişen yapısına katkıda bulunan bir eser görevi de görür. Bu konuda öncü değildir, ondan daha evvel böyle bir bilgi yaratma işini Halep'de Alexander Russell denemiştir. Russell'ın The Natural History of Aleppo, Containing a Description of the City and the Principal Natural Productions in its Neighbourhood, together with an Account of the Climate, Inhabitants and Disease; Particularly of the Plague, with the Methods used by the Europeans for their Preservation isimli eseri bir Müslüman ülkesindeki gündelik hayat konusunda döneminin mühim bir kaynağıydı. ${ }^{61}$ Lane, the Modern Egyptians'ın girişinde Russell'1 Arap dili ve kültürünü tam manasıyla anlatamadığı yönünde eleştirmişse de onun çalışmasından istifade ettiğini belirtmiştir. ${ }^{62}$

Lane'in Misır'a dair edindiği bilgi birikiminden istifade etmek isteyen 1823'de kurulan The Royal Asiatic Society of Great Britain and Ireland gibi oryantalist amaçlarla kurulmuş dernek ve akademik kurumlar da oldu. ${ }^{63}$ Nitekim 19. yüzyılda Doğu, Hindistan'dır ve bir İngiliz mülküdür. Bu sebeple Yakındoğu'dan geçmek, büyük bir sömürgenin yolu üzerindeki bir yerden geçmek demekti. Doğu maddi bir imgelemle tanımlanmıştı. Dolayısıyla Lane'in eserinde gözlem ve detaylı araştırmalarla ortaya koyduğu bilgi, İngiltere'nin bir doğu ülkesi üzerindeki müstakbel siyasi idaresi için bir veri arzıdır. ${ }^{64}$ Said'in topyekûn Lane'nin çalışmalarına muhalefet etmesinin arkasında yatan bilinç bu şekilde izah edilebilir: "Batı'ya özgü gayri şahsi bir inanç ve gerçeklikleri Doğu'dan çok, kendi gözlemlerinden üretme eğilimi"'ndeydi. ${ }^{65}$

59 Irwin, Oryantalistler ve Düşmanlarl, s. 285.

60 Lane-Poole, Life of Edward William Lane, s. 84. Ayrıca bkz. Sophia Lane Pool, The English Women in Egypt: Latters form Cairo, Written during a Residence There in 1845-46 with E. W. Lane, Charles Knight and Co. London 1846, Jason Thomson, "Small Latin And Less Greek: Expurgated Passages From Edward William Lane's 'An Account Of The Manners And Customs Of The Modern Egyptians'”, Quaderni di Studi Arabi, 1, 2006, s. 7.

61 Alexander Russell, 1745-1753 yılları arasında Halep’te İngiliz Levant Company’nin tüccarları için doktorluk yapmıştır. 1756 ' da ilk defa basılan eserinde, nüfus, dil, giyim, kahve ve tütün tüketimi, ibadet, aile hayatı eğlence ve cenaze törenleri gibi konulara yer vermişti. Alexander Russell, The Natural History of Aleppo, containing a Decription of the City and the Principal Natural Productions in its Neighbourhood, together with an Account of the Climate, Inhabitanta and Disease; Particularly of the Plague, with the Methods used by the Europeans for their Preservation, Printed for G.G. and J. Robinson, London 1969. Ayrica bkz. Irwin, Oryantalistler ve Düşmanlarl, s. 126.

62 Lane, The Modern Egyptians, s. XXIV.

63 Said, a.g.e., s. 176. Bu konuda ayrica bkz. Anouar Abdel-Malek, "Orientalism in Crisis”, Diogenes, 11, 44, 1963, s. 106-107. Bilgenoğlu, Çiftçi, "Bir Batılı Seyyahın Hatıralarında”, s. 50.

64 Said, a.g.e., s. 185.

65 Said, s. 187. 
Diğer taraftan Lane'in Misır'daki günlerinde kendisine mihmandarlık yapan ve aynı zamanda bilgi kaynaklarından Ahmet isimli bir Mısırlıdır. Lane’in Müslüman gibi davranarak Ahmet'le camide namaz kıldığını anlatması, Edward Said tarafından sahte mümin/ayrıcalıklı Avrupalı diye samimiyetsizlikle suçlanmasına sebep olmuştur. ${ }^{66}$ Fakat Rodenbeck'e göre Lane'in amacı bu durumu meşru kılar, the Modern Egyptians'ın "bilimsel geçerliliği adına, Mısır ile Mısırlıları tamamıyla ortaya sermek için” bu yöntemi izlediğini iddia etmiştir. Aslında yapmaya çalıştığ 1 şey, Mısırlıların hayatında gezinmektir ve bazen bir Mısır evinin gündelik alışkanlıklarına ve ev yaşamının mahrem taraflarına kadar uzanır. John Rodenbeck, Said'in tezine karşı çıkarak, onun Arap ya da Mısır toplumuna karşı iki yüzlü davranmadığını söyler, aynı zamanda Mısır'ı kendisi için bir cennet ilan ettiğini, onun Mısırla ilgili "her zaman benim için bir memleket olacak" sözünü hatırlatır. ${ }^{67}$

\section{Binbir Gece Masalları: "Elf Leyle ve Leyle"}

1838-40 y1llarında Lane, Binbir Gece Masallarl (Elf Leyle ve Leyle) ya da Arap Eğlenceleri'nin çevirisiyle meşgul oldu. Genelde Doğu, özelde Arap toplumunun dil ve kültürüne vakıf olacağı önemli bir kaynaktı. Binbir Gece Masalları'nın önceki çevirisi hataların olması ve pek de Doğu'yu yansıtmamasıyla eleştirilir. Mesela Antoine Galland (1646-1715), bu masalların kahramanlarını kendi zamanının Parislileri gibi konuşturmakla ve bu anakronizmi doğru çeviri ile dengeleyememekle tenkit edilmişti. ${ }^{68}$ Lane'nin çevirisini de kusurlu bulanlar vardı; Edward Said, Binbir Gece Masalları'nı “esin yoksunu” olarak eleştirir. ${ }^{69}$ Diğer taraftan Borges, Lane'den sonra Binbir Gece Masalları'nı yeniden İngilizceye tercüme eden Richard Burton'unkiyle yaptığı kıyaslamada "Lane (tensel şeyler dışında yalan söylemeyi beceremezdi) onları aslına sadık kalarak akıcı bir nesirle aktarmıştı" demektedir. Hatta Jorge Luis Borges, Burton'u, Lane'in hasmı olarak ilan ettikten sonra, Lane'in kullandığı nesir/düzyazısal üslubun Burton'1 öfkelendirdiğini ve tercihini metni İngilizce dizelere dökmekten yana kullandığını belirtmiştir. ${ }^{70}$

66 Said, a.g.e., s. 172, John Rodenbeck, "Edward Said and Edward William Lane", Travellers in Egypt, ed. Paul Starkey, Janet Starkey, I. B. Tauris, London 1998, s. 234.

67 Rodenbeck, "Edward Said and Edward William Lane", s. 236-239. Ayrıca bkz. Anita Damiani, Enlightened Observers, British Travellers to the Near East 1715-1855, American Univ. of Beirut, Beyrut 1979, Dennis Porter, Haunted Journeys: Desire and Transgression in European Travel Writing, Princeton Univ. Press 1991, Jason Thompson, “Of The 'Osma'nlees, Or Turks': An Unpublished Chapter from Edward William Lane's Manners and Customs of the Modern Egyptians", Turkish Studies Association Bulletin, 19, 2 1995, s. 19-39.

68 Antoine Galland Binbir Gece Masalları'nın, 12 cilt halinde, 1704 ile 1717 yılları arasında çevirisini yapmıştı. Bkz. Mohamad Ali Hachicho, "English Travel Books about the Arab Near East in the Eighteenth Century", Die Welt des Islams, 9, 1/4, 1964, s. 136, Ahmed, Edward William Lane, s. 141.

69 Said, a.g.e., s. 175.

70 Borges bu iddiasını, Burton'ın Babil Kitaplığı serisinden yayınlanan, Binbir Gece Masalları'nın ön sözünde dile getirmiştir. s. 9. Ayrıca bkz. Ahmed, a.g.e., s. 160, Sir Richard Burton, pointed out the unfairness of this in his personal narrative of a Pilgrimage to El-Medinah and Meccah, II, London 1855. 
Binbir Gece Masallarl, Doğu'nun hikâye repertuarının Batı coğrafyasına aktarıldığı en önemli kültürel eserlerden biridir. 19. yüzyılda okuyucular ve akademisyenler daha eksiksiz, standart bir baskı arıyorlardı. Lane, Mısır elyazmalarından tercüme ederek, bir kitap üretmeyi başarmıştır. ${ }^{71}$ Lane'nin çevirisinde her bölüme eklenmiş hayatı ve karakteristik yapıyı gösteren notlar, bir Arap Ansiklopedisi oluşturur mahiyettedir. Tüm metin adeta Doğu'ya ait nesnelerin üzerine kuruludur: Elbiseler, peçeler, mücevherler, evin farklı odaları, sofra adab1, tabaklar, şişeler, müzik aletleri... Fakat Lane'in çevirisinin orijinal ve aşılamaz bir noktasını da William Harvey (1796-1866)'in yaptığı çizimler oluşturmaktaydı. ${ }^{72}$ Lane'in Binbir Gece Masalları çevirisi önce Yararlı Bilgileri Yayma Cemiyeti (the Society for the Diffusion of Useful Knowledge) tarafından yayınland1. ${ }^{73}$ Binbir Gece Masalları Victoria çağ İngiliz okurlarına Doğu'nun fantastik dünyasının kapılarını aralamıştı: Halifeler, prensesler, büyücüler ve cinler... ${ }^{74}$ Lane'in çeviride sık sık verdiği açıklamalar, sözlü öykü anlatımı konusuna ve bu fantastik anlatıların yerel inanç sistemlerindeki yeriyle ilişkilendirilmiştir. ${ }^{75}$

\section{Kahire'ye Son Seyahat: Arapça'ya Adanmış Bir Ömür}

Arabic English Lexicon'un girişinde Edward William Lane, 1842 ile 1849 aralığında gerçekleştirdiği üçüncü Mısır ziyaretinin arka planını anlatmaktadır. "1842 yılında Northumberland Dükü (Lord Prudhoe) Algernon tarafindan bana şimdiye dek yapılan en cömert teklif, bu çalışmanın sorumluluğunu üstlenmemi sağladı... Teklif edilen şey İngilizce'de Golius ${ }^{76}$ ve diğerlerinin zaten Latince yapmış olduklarından biraz daha fazlasını yapmak değildi, epitomlar veya özetler ya da el kitapçığı sınıfından birkaç Arapça sözlüğü çevirip bir araya getirmek; fakat en zengin Arap kaynaklarından esas olarak yararlanmak... Orada (Kahire'de), Avrupa'da bilinmeyen başka kaynaklar bulabileceğime ve projemin ilerlemesi ve daha fazla yardım alabileceğime inanmak için nedenim vardı; ve bu amaç için yola koyuldum." $" 77$

71 Edward William Lane, The Thousand and One Nights: Commonly Called, in England, The Arabian Nights Entertainments, c. 1, Routledge, London 1865, s. XII.

72 Bkz. Jennifer Schacker-Mill, "Otherness and Otherworldliness: Edward W. Lane's Ethnographic Treatment of The Arabian Nights", The Journal of American Folklore, 113, 448, 2000, s. 164-184. Arthur John Arberry, Oriental Essays, Portraits of Seven Scholars, Ruskin House, George Allen and Unwin, London 1960, s. 104106. Aliakbari, "The Arabian Nights in the English Popular Press", s. 444, 446, Ulrich Marzolph, "The Arabian Nights in Comparative Folk Narrative Research", The Arabian Nights and Orientalism, Perspectives from East and West, ed. Yuriko Yamanaka, Tetsuo Nishio, I. B. Tauris, London 2006, s. 5. 3-24.

73 Schacker-Mill, "Otherness and Otherworldliness", s. 167.

74 Robert Irwin, The Arabian Nights: A Companion, I. B. Tauris, London 2004, s. 23.

75 Irwin, Oryantalistler ve Düşmanlarl, s. 169, ayrıca J. Hetworth-Dunne, "Printing and Translations under Muhammad Ali of Egypt: The Foundation of Modern Arabic", Journal of the Royal Asiatic Society, 1940, s. 325-349. Aoyagi, Etsuko (2006). Repetitiveness in the Arabian Nights: Openness as Self-foundation. The Arabian Nights and Orientalism, Perspectives from East and West, ed. Yuriko Yamanaka, Tetsuo Nishio, I. B. Tauris, London s. 68-90.

76 Leiden Üniversitesi'nde matematikçi ve oryantalist olarak çalışan Jocob Golius (1596-1667) daha ziyade Arapça'dan Latince'ye yaptığı çevirilerle tanınmaktadır. En iyi bilinen çalışması Arapça-Latince sözlük, Arabico-Latinum (1653)'u daha ziyade el-Cevheri'nin Șị̂hhu'l-luga (Tâcü'l-luga) ve Firûzâbâdî'nin elKāmûsü'l-muhîț'ini kaynak almıştır. Bkz. Turgut Akpınar, “Golius, Jacobus”, DİA, 14, 1996, s. 111-112.

77 Edward William Lane, Arabic-English Lexicon, Willams \& Norgate, London 1863, s. V. 
Lane, Mısırlı bir alimin yardımına ihtiyaç duyduğunu da belirterek, bir Fransız oryantalist Fulgence Fresnel (1795-1855)'e haber göndermiş ve ayrıca onu "yılda 200 Sterlin maaşla" projesine katılmaya davet etmişti. ${ }^{78 ~ “ . . . K a h i r e ’ y e ~ g e l d i g ̆ i m d e, ~ e v v e l a ~}$ Mısır'daki önceki ikametim sırasında dostluk kurduğum, başarılı bir Arapça alimi olan merhum M. Fulgence Fresnel'e hazırlıklarımı yaparken yardım etmesi için başvurdum." ${ }^{\text {79 }}$ Fresnel, el yazması eserleri kopyalama, tercüme etme amacıyla Ezher şeyhi İbrâhim b. Abdülgaffâr ed-Desûkî (1811-1883)'yi ${ }^{80}$ Lane'e asistan olarak tavsiye etmişti. ${ }^{81}$ Lane, “Fresnel beni, ihtiyaç duyduğum hizmetler için Şeyh Ed-Desûkî'den başka daha nitelikli birini Kahire'de bulamayacağıma ikna etti ve başka bir asistan çalıştırma firsatım olmadı, zaman zaman onun gözetiminde transkriptörlerle de çalıştım." 82 Diğer taraftan son Misır seyahatine eşlik eden yeğeni Stanley Lane Pool, ed-Desûkî'yi "huysuz ve paragöz" biri olarak tanımlamakla birlikte, Edward W. Lane'nin Muhammed Bey Camii'inden istediği yazmaları onun sayesinde alabildiğini de belirtmiştir. ${ }^{83}$

Desûkî, Lane'in hayatında dostluk ve bilimsel işbirliğinin temsiliydi. Bu işbirliğinden Arabic-English Lexicon ortaya çıkacaktır. Bu sözlüğün oluşması sırasında bazı temel Arapça kaynaklar konusunda Lane'e yol gösterdiği, temin ettiği ve hatta bazılarının tercümesine yardım ettiği anlaşılmaktadır. Lexicon'un teşekkülünde ön plana çıkan klasik eserler, Süyûtî’nin sözlük metodolojisine dair el-Müzhir fî Ulûmi'l-Luga ${ }^{84}$ adlı eseri, devamında Murtazâ ez-Zebîdî (Ö. 1791)'nin Tâcü'l-Arûs'unu ve hatta hazırlanan sözlüğün temel

78 Suha Kudsieh, "Beyond Colonial Binaries Amicable Ties among Egyptian and European Scholars 1820-1850", Alif: Journal of Comparative Poetics, 36, 2016, s.55.

79 Lane, Arabic-English Lexicon, 1863, s. V.

80 El-Desûkî 1811 'de dünyaya gelmişti. İlk eğitimini Desûk'da aldıktan sonra el-Ezher'de öğrenimine devam etmişti. Ezher'de kısa bir süre ders verdikten sonra yükssek öğrenim kurumlarında kullanılmak üzere oluşturulan ders kitaplarının tashihi işine tayin edildi. Nihayet Hidiv İsmail Paşa zamanında Bulak'daki devlet matbaasında baş musahhihlik (baş okuyucu) görevine atandı. Bir süre Mısır resmi gazetesi Vaka-yi Mısriyye'nin editör yardımcılı̆̆ını yapmıştır. I. Goldziher, “Al-Dasûkî, Al-Sayyid İbrahim b. İbrahim”, EI, c. 2, s. 167.

81 Sadgrove, Durmuş, "Lane, Edward William”, s. 99, Roper, "Texts from Nineteenth Century Egypt", s. 248, Sophia Lane-Poole, Life of E. W. Lane, s. 117, Irwin, Oryantalistler ve Düşmanlarl, s. 169, Suha Kudsieh, "Beyond Colonial Binaries Amicable Ties among Egyptian and European Scholars 1820-1850", Alif: Journal of Comparative Poetics, 36, 2016, s. 44-68

82 Goldziher, a.g.m., s. 167, Kudsieh, "Beyond Colonial Binaries Amicable Ties", s. 55, Lane-Poole, Life of Edward William Lane, s. 117.

83 Lane-Poole, a.g.e., s. 118. Diğer taraftan Lane Kahire'ye son ziyaretini gerçekleştirmeden önce tamamladığ1 bir başka eseri Selections from the Kur 'ân 1843 'te o Kahire'deyken yayınlandı. Kitabın giriş kısmında Lane, İslam öncesi Arap toplumunun tarihi ve kültürel özellikleri, akabinde Hz. Muhammed, İslam'ın doğuşu ve Kuran'1 anlatmıştır. Birinci bölümde Kuran'da geçen Allah, cennet ve cehennem, melekler ve cinler gibi kavramları açıklamıştır. Kitabın ikinci bölümünü ise peygamberler ve kutsal kitaplara ayırmıştır. Bkz. Edward William Lane, Selections from the Kur'ân, Houghton, Osgood and Company, Boston 1879.

84 Edward William Lane'in kendi sözlüğü için kaynak olarak kullandığı bu eser, Arap sözlük bilimi ve metodolojisiyle Arap dil bilimi ve fikhü'l-luga hakkında kapsamlı ilk eserdir. Yazma halindeki El-Müzhir, ilk defa Nasr el-Hûrî’nin yaptığı düzeltmelerle Bulak matbaasında 1865/1866'da yayınlanmıştır. Bkz. Süleyman Tülücü, “el-Müzhir”, DIAA, 32, 2006, s. 251-252. 
kaynaklarını Fîrûzâbâdî (Ö. 1415)'nin el-Kâmûsü'l-Muhît ț'i oluşturmaktadır. ${ }^{85}$ Lane'in sözlüğün hazırlanması esnasındaki çalışma tarzını yeğeni Stanley Lane Pool, "kullandığı bir bilginin her zaman kaynağını da verirdi. Zayıf bir otoriteyi dayanak göstermezdi” şeklinde açıklamıştı. Kaynağın zayıflığından kastettiği şey ise “İslam'ın klasik çağında yaşamamış ya da bozuk bir lehçe konuşan bir kabileye ait kaynaklardı" ${ }^{86}$ Lane'nin bir araya getirdiği yerli sözlüklerin sayısı, teknik ifadeler ve çelişkili tarafları dikkate alınacak olunursa tüm bunları bir sözlükte uzlaştırmak bir ömre sığmayacak bir işti.

Lane'nin çalışmaları, Mısırlı Ali Mübarek ${ }^{87}$ (1823-1893) gibi Fransa' da bir süre yaşamış Misırlı bürokrat ve entelektüeller tarafından takip ediliyordu. ${ }^{88}$ Ayrıca Misır idarecilerinin Lane'nin çalışmalarından haberdar oldukları da görülmektedir. Nitekim Mehmed Ali Paşa'nın yardımcısı Artin Bey, Lane'i çalışmasında desteklerini iletmek için huzuruna davet etmişti. Ne var ki, camilere ellerindeki el yazmalarını Lane’e ödünç vermesini söylemek, Mehmed Ali'nin bile yetkisinin ötesindeydi. ${ }^{89}$ Bu noktada Ed-Desûkî'nin önemli bir işleve sahip olduğunu bir kez daha anlıyoruz. O günlerde Mısır'daki "halk kütüphaneleri” camilere bağlıydı ve Lane, şeyhlerin ve cami ulemasının bu eserleri bir yabancıya ödünç verme konusunda cömert davranmayacaklarını biliyordu. ${ }^{90}$

Son seyahatini Arabic-English Lexicon için malzeme toplamak amaciyla yapan Lane, hayatının geriye kalan 35 yılını bu konuya adadı, ancak bu projeyi tamamlayamadı. Lane'in klasik Arap literatürünü iyi bilmesi ve yerel kaynaklara dayanarak bir sözlük yazması kapsamlı bir çalışmanın ortaya çıkmasını sağladı. Yaklaşık yirmi yıl süren hazırlığın ardından ilk cilt 1863 'te yayınlanmış; diğer dördü iki ila üç yıllık aralıklarla basılmıştır, hayattayken altıncı cildi de yayınlayabilmiştir. Sözlüğün ortaya çıkma sürecinde masrafları Northumberland Dükü üstlenmişti; bu cömert davranış Northumberland Dükü'nün ölümünden sonra, eşi Düşes Eleanor (1820-1911) tarafından da devam ettirildi. İngiliz Hükümetinden ayrıca, Lane'in çalışmalarına her zaman sempati duyan ve 1846-1852 ile 1865-1866 yılları arasında iki defa başbakanlık yapan Earl John Russell (1792-1878), Özel Hizmet Fonu'ndan üç defa hibe verdi. Ayrıca Kraliçe Victoria da Kraliyet bütçesinden (hazine-i hassa) bir emekli aylığı tahsis etmişti. ${ }^{91}$

85 Sadgrove, Durmuş, "Lane, Edward William", s. 99. Ayrıca Bkz. Roper, "Texts from Nineteenth Century Egypt", s. 250. A. J. Arberry, "The Lexicographer: Edward William Lane", Oriental Essays: Portraits of Seven Scholars, Allen and Unwin, London 1960, s. 87-121, Miroslav Krek, "E. W. Lane's Working Copy of His Lexicon", Journal of the American Oriental Society, 89, 2, 1969, s. 419-420. İsmail Durmuş, "Zebîdî, Muhammed Murtazâ1, DİA, 44, 2013, s. 169, Hulusi Kılıç, "El-Kāmûsü'l-Muhît”, Di்A, 24, 2001, s. 287-288.

86 Lane-Poole, Life of Edward William Lane, s. 104.

87 El-Hitatü 't-Tevfikıyyetü'l-cedîde (1306) isimli eserinde de Lane'nin çalışmalarından bahsetmiştir. Kâzım Yaşar Kopraman, "Ali Paşa Mübârek", DİA, 2, 1989, s. 433-434.

88 Goldziher, a.g.m., s. 167.

89 Lane-Poole, Life of Edward William Lane, s. 118.

90 Kudsieh, "Beyond Colonial Binaries Amicable Ties", s. 55.

91 Lane-Poole, Life of Edward William Lane, s. 109, Fleischers, "Edward William Lane, 10 August 1876", Zeitschrift der Deutschen Morgenländischen Gesellschaft, 30, 3, 1876, s. 614. 
Bütün bu taltif ve ödüller aslında onun tavizsiz ve fasıla vermeyen çalışkanlığının takdiriydi. Öyle ki kendisiyle Kahire'de görüşebilen sınırlı sayıdaki İngiliz dostları onun Arapça sözlük için günde on iki saati aşkın mesai harcadığını belirtirler. ${ }^{92}$ Mola ve istirahat için seçtiği gün ise manidardı: Cuma günü. Sadece Müslümanların mübarek gününde arkadaşlarını kabul ediyordu. Gönüllü bir münzeviliği seçmesinin, neredeyse tüm zamanını sözlüğe tahsis etmesinin bir diğer şahidi de yeğenidir: Misır' da ailesiyle birlikte geçirdiği son Kahire yıllarında o sıralar henüz çocuk olan yeğen Stanley Lane-Pool, bütün bu süre zarfinda dayısının piramitleri sadece bir kez o da üç günlüğüne gezdirmeye götürmesinden naif bir hoşlukla bahsedecektir. ${ }^{93}$

Lane Mısır'dan Londra'ya-bir daha dönmemek üzere- 1849 yılında avdet eder; eşi Nefíse, kız kardeşi Sofia Lane-Poole ve iki yeğeni ile birlikte bir yıl Hastings'de kaldıktan sonra 1851 'de Worthing'e yerleşir. Burada da oldukça küçük bir arkadaş çevresi içinde yaşar. ${ }^{94}$ Kahire'deki çalışma temposunu sürdürür. Tek gayesi Lexicon’u itmam etmektir. Bu arada üyesi olduğu Deutsche Morgenländische Gesellschaft (Alman Şark Cemiyeti) ${ }^{95}$ Dergisi'nde iki makalesi yayınlanır; her iki makale de Arapça telaffuz ve sözlükbilimi (lexicology) üzerinedir. ${ }^{96}$

Edward W. Lane'in oryantalizm, hususen Arabça vadisindeki tetkikleri ülkesi dişında da tasdik görür, 1864 yılında oy birliği ile Fransız Académie des Inscription et Belles Lettres'e üye olarak seçilir. 11 yıl sonra, 1875'te Leiden Üniversitesi de ona, kuruluşunun 'Üç Yüzüncü Y1lı Festivali'nde Fahri Edebiyat Doktorası vermekten şeref duyacaktır. ${ }^{97}$ Bunlar Lane'nin 1876 'da vefat etmeden önce aldığg son payelerdir.

\section{Sonuç}

1801-1876 yılları arasında yaşayan Edward William Lane ilkin, ülkesinin öncülük ettiği sanayi ve emperyalizm çağının, demiryollarının, buharlı gemilerin mesafeleri kısalttığ bir yüzyılın insanıdır. Fakat o Kahire ve/ya Birmanya olsun merkezi Londra'da olan bir

92 Lane-Poole, a.g.e., s. 110.

93 Lane-Poole, a.g.e., s. 116-117.

94 Fleischers, a.g.m., s. 615, Thompson, Sir Gardner Wilkinson and His Circle, 2013, s. 139.

952 Ekim1845'te Leipzig'de Deutsche Morgenländische Gesellschaft'ın kurulmasıla Almanya'da 19. yüzyılın ilk yarısında akademik oryantalizmin kurumsal temelleri atılmıştı. Derneğin yayınları arasında Zeitschrift der Deutschen Morgenländischen Gesellschaft (ZDMG) (ilk sayısı 1847) yer almaktadır. Lane bu derneğe 'Kahire muhabiri' olarak kayıt edilmişti. https://dmg-web.de/page/geschichte_en (Erişim Tarihi: 18.04.2020) bkz. Verzeichniss der Mitglieder der Deutschen Morgenländischen Gesellschaft. Zeitschrift der Deutschen Morgenländischen Gesellschaft, 2, 4, 1848, s. 514.

96 E. W. Lane, "Ueber die Aussprache der arabischen Vocale und die Bctonunng der Arabischen Wörter", Zeitschrift der Deutschen Morgenländischen Gesellschaft, 4, 2,1850, s. 171-186, Edward William Lane, "Ueber die Lexicographie der Arabischen Sprache", Zeitschrift der Deutschen Morgenländischen Gesellschaft, 3, 1, 1949, s. 90-108.

97 Fleischers, a.g.m., s. 616. 
şirketin acentası ya da sömürge memuru olarak bulunmaz. Lane'nin yazılarında İngiliz sömürge çıkarlarının korunmasına yönelik hiç bir tavsiye yer almaz. Bu açıdan o Britanya emperyalizmini savunan Rudyard Kipling (1865-1936)'den farklıdır.

Lane'nin Doğu ilgisi, kendi çağının Nerval ve Flaubert gibi şöhretli Fransız ediplerinin burjuva Avrupa'nın sıkıntısının teşvik ettiği dikkatli ve detaylı gezi notlarının da fazlasını içerir. Bu çerçevede Lane'in Doğu hevesi ve oryantalizmi üç noktada özetlenebilir: İlkin o en başarılı Binbir Gece Masalları mütercimlerinden biridir, Lane sadece bu tercümenin getireceği şöhretle de pekâlâ yetinebilirdi. İkinci olarak Arapça-İngilizce sözlük çalışması da, Binbir Gece Masalları gibi, âlimlik gerektiren, ilim dalı olarak oryantalizm içinde değerlendirilecek uğraşlar, salt akademik tetkik ve çevirilerdir. Son olarak Lane bir Misır/ Kahire antropoloğudur, içinde yaşayarak, tecrübe ettiği bir Mısır gözlemcisidir. Başka bir ifadeyle onun Şarkı, İran ya da Babil değil, Mısır ve özelikle Kahire'dir. Mısır'a yönelik Avrupa ilgisinin Napolyon Bonapart'ın 1798 yılında bu beldeyi işgal etmesiyle başladığı̆, askeri rekabetin yanı sıra Fransız-İngiliz alim veya oryantalistlerin yarışını da içerdiği harc-1 alem bir bilgidir. Edward William Lane ve çalışmaları hakkında menfi veya müsbet farklı görüşlerin olduğu aşikardır. Fakat bu makale Lane'in ve temsil ettiği varsayılan etnografik veya bilimsel yaklaşımın savunmasına dayanmamaktadır. Lane'den hareketle oryantalizmin pekala bilimsel bilgileri içerebildiğini görmekteyiz. Meselenin özünde Doğu'ya ait bilimsel bilgi ve olgu üretme sorunu yer almaktadır. Zira tüm oryantalizm, "emperyal iktidar ve bilimsel bilginin bir araya gelmesinden güç alır".

Lane, ilk seyahatinde, çağının ruhuna uygun olarak Antik Mısır'a yönelik merakıyla hareket ediyordu. Lakin bir süre sonra ölü ve yüce firavunlar yerine yaşayan, mütevazı Araplara ilgisini yöneltti. Halihazırda Osmanlı İmparatorluğu'nun idaresi altındaki Mısır'da yönetici sınıfın değil de sıradan Arapların hayatını, Avrupalı bir gözlemci olarak kaydetmeye başladı. Bu sebeple Mısır'ın antik harikalarını gün yüzüne çıkaran Description of Egypt'den, çağdaşı Mısırlıların adet ve geleneklerini anlattığı The Modern Egyptian'a yönelir. Elbette yabancı bir cemiyeti anlamanın yolu, dilini öğrenmekten geçiyordu. Lane'nin Arapça öğrenme serüveni, 1840'lardan itibaren ölümüne kadar meşgul olacağı ve fakat tamamlayamayacağı Arapça-Ingilizce Sözlük çalışmasıyla taçlanır.

Lane ve sair oryantalistleri Mısır'a yönelik özel bir merak ve teveccüh göstermelerine zaman izin vermişti. Antik Mısır arkeolojisi, firavunların hazineleri, heykelleri, parşömenleri 1798'den beri heveskar Avrupalıların değişik derecelerden ilgisini çekiyordu. Daha evvel Hamilton ve Niebuhr kitaplarıyla Mısır çalışmaları konusunda çı̆̆ır açmışlardı; ancak ülkenin sistematik bir haritası, doğal özellikleri, halkının âdetleri ve tarihi anıtları henüz kayıt altına alınıp kataloglanmamıştı. Lane'i diğerlerinden farklı kılan, yağmacı heveslerden uzak durması ve Mısır'daki hayatını Avrupal1-efendi gibi yaşamamasıydı. Öte yandan, Lane'nin Mısırlıları henüz daha alla francalılaşmamış ve kendi sahiciliğini koruyordu. 
Hakem Değerlendirmesi: Dış bağımsız.

Çıkar Çatışması: Yazar çıkar çatışması bildirmemiştir.

Finansal Destek: Yazar bu çalıșma için finansal destek almadığını beyan etmiștir.

Peer-review: Externally peer-reviewed.

Conflict of Interest: The author has no conflict of interest to declare.

Grant Support: The author declared that this study has received no financial support.

\section{Kaynakça/References}

Abdel-Malek, Anouar, “Orientalism in Crisis”, Diogene, 11, 44, 1963, s. 103-140.

Ahmed, Leila, Edward William Lane, A Study of his Life and Works and of British Ideas of the Middle East in the Nineteenth Century, Longman, London 1978.

Abu-Lughod, Janet, Cairo: 1001 Years of the City Victorious, Princeton University Press, Princeton 1971.

Akpınar, Turgut, “Golius, Jacobus”, DİA, 14, 1996, s. 111-112.

Aliakbari, Rasoul, "The Arabian Nights in the English Popular Press and the Heterogenization of Nationhood:

A Print Cultural Approach to Benedict Anderson's Imagined Communities", Canadian Review of Comparative Literature / Revue Canadienne de Littérature Comparée, 43, 3, 2016, s. 439-460.

Alsayyad, Nezar, Cairo: Histories of a City, Belknap Press of Harvard University Press, Cambridge 2011.

Aoyagi, Etsuko, "Repetitiveness in the Arabian Nights: Openness as Self-foundation", The Arabian Nights and Orientalism, Perspectives from East and West, ed. Yuriko Yamanaka, Tetsuo Nishio, I. B. Tauris, London 2006, s. 68-92.

Arberry, Arthur John, British Orientalists, William Collins, London 1943.

Oriental Essays: Portraits of Seven Scholars, Allen and Unwin, London 1960.

Bilgenoğlu, Ali- Çiftçi Selahattin Ertürk, "Bir Batılı seyyahın Hatıralarında Oryantalizm'in İzlerini Sürmek: Edward William Lane'in Gözünden 19. Yüzyıl Mısır Toplumu ve Kültürü’, Tarih Okulu Dergisi, 11, 36, 2018, s. 43-62.

Bowring, John, Report on Egypt and Candia Adressed to the Right Hon. Lord Viscount Palmerston, Her Majesty's Principal Secretary of State for Foreign Affairs, W. Clowes and Sons, London 1840.

Burchardt, John Lewis, The Manners and Customs of the Modern Egyptians, London.

Burton, Richard F., Binbir Gece Masalları, Babil Kitaplığı haz. Jorge Luis Borges, çev. Gülgün Bayata, Kırmızı Kedi Yay., İstanbul 2015.

Carne, John, Recollections of Travels in the East, London 1830.

Damiani, Anita, Enlightened Observers, British Travellers to the Near East 1715-1855, American Univ. of Beirut, Beyrut 1979.

Davies, Richard A., Inventing Sam Slick: A Biography of Thomas Chandler Haliburton, University of Toronto Press, Toronto 2005

Durmuş, İsmail, “Zebîdî, Muhammed Murtazâ”, DİA, 44, 2013, s. 168-171.

Elwood, Anne Katherine, Narrative of a Journey Overland from England, 1-2, London 1830. 
Farouk Ahmed, Heba, Pre-Colonial Modernity: The State and the Making of Nineteenth-Century Cairo's Urban Form, Yayınlanmamış Doktora Tezi, University of California, Berkeley 2001.

Fleischers, "Edward William Lane, 10 August 1876", Zeitschrift der Deutschen Morgenländischen Gesellschaft, 30, 3, 1876, s. 612-616.

Goldziher, I., “Al-Dasûkî, Al-Sayyid İbrahim b. İbrahim”, $E I^{2}, 2$, 2012, s. 167.

http://dx.doi.org/10.1163/1573-3912_islam_SIM_1735 (Erişim Tarihi: 20.4.2020)

Fahmy, Ziad, Ordinary Egyptians, Creating the Modern Nation Through Popular Culture, Stanford University Press, Stanford 2011.

Goldschmidt Jr., Arthur, Historical Dictionary of Egypt, Scarecrow Press, Plymouth 2013.

Hachicho, Mohamad Ali, "English Travel Books about the Arab Near East in the Eighteenth Century", Die Welt des Islams, 9, 1/4, 1964, s. 1-206.

Halls, J. J., The Life and Correspondence of Henry Salt ESQ. FRS. His Britannic Majesty's Late Consul General in Egypt, 2, Richard Bentley, London1834.

Harlow, Barbara, “Cairo Curiosities: E. W. Lane's Account and Ahmad Amin's Dictionary", Journal of the History of Ideas, 46, 2, 1985, s. 279-286.

Hay, Robert, Illistrutation of Cairo, Tilt and Bogue, London 1840.

Hetworth-Dunne, J., "Printing and Translations under Muhammad Ali of Egypt: The Foundation of Modern Arabic", Journal of the Royal Asiatic Society, 1940, s. 325-349.

Holt Yates, William, The Modern History and Condition of Egypt, 1-2, London 1843.

Irwin, Robert, The Arabian Nights: A Companion, I. B. Tauris, London 2004.

"Political Thought in the Thousand and One Nights", The Arabian Nights in Transnational Perspective, ed. Ulrich Marzolph, Wayne State UP, 2007, s. 103-119.

Oryantalistler ve Düşmanları, çev. Bahar Tırnakcı, Yapı Kredi Yayınları, İstanbul 2008.

"The Arabian Nights and the Origins of the Western Novel", Scheherazade's Children: Global Encounters with the Arabian Nights, ed: Marina Warner and Philip Kennedy, New York 2013, s. 143153.

Kilıç, Hulusi. "El-Kāmûsü'l-Muhît”, DİA, 24, 2001, s. 287-288.

Kopraman, Kâzım Yaşar, “Ali Paşa Mübârek”, DİA, 2, 1989, s. 433-434.

Krek, Miroslav, “E. W. Lane's Working Copy of His Lexicon”, Journal of the American Oriental Society, 89, 2, 1969, s. 419-420.

Kudsieh, Suha, "Beyond Colonial Binaries Amicable Ties among Egyptian and European Scholars 18201850", Alif: Journal of Comparative Poetics, 36, 2016, s. 44-68.

Lane, E. W., "Ueber die Lexicographie der arabischen Sprache”, Zeitschrift der Deutschen Morgenländischen Gesellschaft, 3, 1, 1849, s. 90-108.

"Ueber die Aussprache der arabischen Vocale und die Bctonunng der arabischen Wörter", Zeitschrift der Deutschen Morgenländischen Gesellschaft, 4, 2, 1850, s. 171-186. Arabic-English Lexicon, Willams \& Norgate, London 1863.

The Thousand and One Nights: Commonly Called, in England, The Arabian Nights' Entertainments, c. 1, Routledge, London 1865. 
Selections from the Kur'ân, Houghton, Osgood and Company, Boston 1879.

Description of Egypt, Ed. Jason Thompson, American University in Cairo, Cairo 2000.

Lane Pool, Sophia, The English Women in Egypt: Latters form Cairo, Written during a Residence There in 1845-46 with E. W. Lane, Charles Knight and Co. London 1846.

Lane-Poole, Stanley, The story of Cairo, J. M. Dent Co., London 1906.

Life of Edward William Lane, Williams and Norgate, London 1877.

Madden, R., Travels in Turkey, Egypt, and Palestine in 1824,1825,1826, 1827, 1-2, London 1829.

Madox, John, Excursions in the Holy Land, Egypt, Nubia, Syria, 1-2, London 1834.

Mahmoud, Shadia, "Nationalization and Personalization of the Egyptian Antiquities: Henry Salt a British General Consul in Egypt 1816 to 1827”, International Journal of Culture and History, 3, 2, 2016, s. 29-43.

Manley, Deborah, The Nile A Traveller's Anthology, Cassell, London 1996.

Peta Rée, Henry Salt: Artist, Traveller, Diplomat, Egyptologist, Libri Publications Ltd., London 2001.

Marzolph, Ulrich, "The Arabian Nights in Comparative Folk Narrative Research", The Arabian Nights and Orientalism, Perspectives from East and West, ed. Yuriko Yamanaka, Tetsuo Nishio, I. B. Tauris, London, 2006, s. 3-24.

McGilchrist, John, The Life and Career of Henry Lord Brougham, Cassell, Petter and Galpin, London 1868. Mitchell, Timothy, Mısır'ın Sömürgeleştirilmesi, çev. Zeynep Altok, İletişim Yay., İstanbul 2001.

Porter, Dennis, Haunted Journeys: Desire and Transgression in European Travel Writing, Princeton Univ. Press, Princeton 1991.

Rodenbeck, John, "Edward Said and Edward William Lane", Travellers in Egypt, ed. Paul Starkey, Janet Starkey, I. B. Tauris, London 1998, s. 233-243.

Roper, Geoffrey, "Texts from Nineteenth Century Egypt: The Role of E. W. Lane”, Travellers in Egypt, ed. Paul Starkey, Janet Starkey, I. B. Tauris, London, 1998, s. 244- 254.

Sadgrove Philip Charles-İsmail Durmuş, Lane, Edward William”, DİA, 27, 2003, s. 99-100.

Said, Edward W. Şarkiyatçılık Batı’nın Şark Anlayışları, çev. Berna Ülner, Metis Yay., İstanbul 2001.

Schacker-Mill, Jennifer, "Otherness and Otherworldliness: Edward W. Lane's Ethnographic Treatment of The Arabian Nights", The Journal of American Folklore, 113, 448, 2000, s. 164-184.

Searight, Sarah, The British in the Middle East, Elton Press, London 1979.

Waldron-Grutz, Jane, "The Lost Portfolios of Robert Hay” Saudi Aramco World, 54, 2, 2003, s. 2-11.

Sherer, Joseph Moyle, Scenes and Impressions in Egypt and in Italy, London 1824.

Starr, Deborah A., "Sensing the City: Representations of Cairo’s Harat al-Yahud", Prooftexts, 26, 1-2, 2006, s. $138-162$.

Thompson, Jason, "Osman Effendi: A Scottish Convert to Islam in Early Nineteenth-Century Egypt”, Journal of World History, 5, 1, 1994, s. 99-123.

““Of The 'Osma'nlees, Or Turks': An Unpublished Chapter from Edward William Lane's Manners and Customs of the Modern Egyptians", Turkish Studies Association Bulletin, 19, 2, 1995, s. 19-39.

"Edward William Lane's 'Description of Egypt”", International Journal of Middle East Studies, $28,4,1996$, s. 565-583. 
"Small Latin And Less Greek: Expurgated Passages From Edward Williamlane's 'An Account Of The Manners And Customs Of The Modern Egyptians"”, Quaderni di Studi Arabi, 1, 2006, s. 7-28. A Catalogue of the Edward William Lane Collection in the Griffith Institute, Oxford, http:// www.griffith.ox.ac.uk/gri/4lane.pdf (Erişim Tarihi: 03.04.2020) Sir Gardner Wilkinson and His Circle, University of Texas Press, Texas 2013.

Tibawi, Abdul Latif, English-Speaking Orientalists A Critique of Their Approach to Islam and Arab Nationalism, Islamic Centre, Geneva 1965.

Tülücü, Süleyman “el-Müzhir”, DİA, 32, 2006, s. 251-252.

Verzeichniss der Mitglieder der Deutschen Morgenländischen Gesellschaft. Zeitschrift der Deutschen Morgenländischen Gesellschaft, 2, 4, 1848, s. 505-515. 